\title{
ANALISIS EFEKTIVITAS DAN KONTRIBUSI PAJAK HOTEL TERHADAP PENDAPATAN ASLI DAERAH KABUPATEN HALMAHERA UTARA
}

\author{
Thressa Resita Pangerapan ${ }^{1}$, Herman Karamoy $^{2,}$ Stanly W Alexander ${ }^{3}$ \\ ${ }^{1}$ jurusan Akuntansi, Fakultas Ekonomi Dan Bisnis, Universitas Sam Ratulangi Manado, Jln Kampus Bahu, \\ Manado 95115, Indonesia \\ E-mail : thressapangerapan@yahoot.com
}

\begin{abstract}
Local Own Revenue (PAD) is regional income derived from the results of local taxes, the results of local retribution, the result of separated regional wealth management, and others. The purpose of this study, to determine the effectiveness and contribution to the North Halmahera District's Original Revenue. The analytical method used is descriptive qualitative that is analyzing the level of effectiveness and contribution from data realization of Hotel Tax District of North Halmahera. The results showed that (1) the effectiveness of Hotel Tax in 2013 until 2017 experienced a decrease and a varied increase. The highest effectiveness is in 2014 with the percentage of $116.08 \%$ and included in the criterion is very effective, then the lowest effectiveness is in 2016 with the percentage of $86.32 \%$ and included in the criterion less effective, (2) Hotel Tax Contribution on 2013 to 2017 goes into very less criteria. And that included in the lowest criterion number is in 2015 with a percentage of $1.82 \%$.

Keywords: Local Original Income, Effectiveness, Contribution
\end{abstract}

\section{PENDAHULUAN}

Pajak daerah adalah sebagai salah satu komponen pendapatan asli daerah memiliki prospek yang sangat baik untuk dikembangkan. Karena pajak daerah yaitu pajak yang wewenang pemungutannya atau dikelola oleh pemerintah daerah (baik pemerintah propinsi maupun pemerintah kabupaten/kota) dan hasilnya dipergunakan untuk membiayai pengeluaran rutin dan pembangunan daerah (APBD).

Kabupaten Halmahera Utara, yang merupakan kota pariwisata mengelola berbagai pajak daerah, salah satunya adalah pajak Hotel. Mengingat pajak Hotel merupakan salah satu penunjang PAD Kabupaten Halmahera Utara maka pemungutan pajak Hotel perlu dioptimalkan. Guna mengoptimalkan penerimaan sumber komponen pajak daerah ini, tentunya perlu dilakukan perhitungan penerimaan pajak Hotel pada dinas pendapatan daerah (DISPENDA) secara cermat dan akurat yang akan bermuara kepada peningkatan realisasi PAD khususnya dari penerimaan pajak Hotel DISPENDA di Kabupaten Halmahera Utara. Tujuan dari penelitian ini adalah untuk menganalisis :

1. Efektivitas pajak hotel terhadap pendapatan asli daerah di Kabupaten Halmahera Utara.

2. Kontribusi pajak hotel terhadap pendapatan asli daerah di Kabupaten Halmahera Utara.

\section{TINJAUAN PUSTAKA}

\subsection{Konsep Akuntansi}

Akuntansi sering disebut sebagai bahasa bisnis atau sering disebut sebagai bahasa dari keputusan bisnis, dan akuntansi pada dasarnya akan menghasilkan informasi dari sebuah sistem akuntansi yang ada didalam sebuah entitas atau organisasi bisnis yang disebut dengan informasi akuntansi yang akan dimanfaatkan oleh penguna seperti masyarakat intelektual (termaksud didalamnya mahasiswa dan peneliti) dan para pengambil keputusan bisnis dalam organisasi. (Lamia, 2015:3) 


\subsection{Pengertian akuntansi}

Pengertian Akuntansi menurut Lubis (2015:2) adalah sistem informasi yang menyediakan laporan bagi para pihak mengambil keputusan (stakeholder) mengenai aktivitas ekonomi dan kondisi perusahaan.

\subsection{Pengertian Akuntansi Perpajakan}

Akuntansi Pajak (Tax Acconting), menjelaskan dalam menetapkan besarnya pajak terutang tetap mendasarkan laporan keuangan yang disusun oleh perusahaan, mengingat dalam ketentuan perundang-undangan perpajakan terdapat aturan-aturan khusus yang berkaitan dengan akuntansi, yaitu dalam masalah konsep transaksi dan peristiwa keuangan, metode pengukurannya, serta pelaporan yang ditetapkan dengan Undang-Undang.

\subsection{Konsep Pajak}

Pajak merupakan faktor penunjang penghasilan di Indonesia. Jadi setiap orang harus membayar pajak, untuk memahami hal tersebut maka perlu terlebih dahulu untuk memahami tentang pengertian pajak itu sendiri. Pajak adalah pungutan wajib yang dibayar rakyat untuk negara dan akan digunakan untuk kepentingan pemerintah dan masyarakat.

\subsection{Pengertian Pajak}

Proses akuntansi dimulai adanya transaksi, yaitu peristiwa yang dapat mengakibatkan berubahnya posisi keuangan perusahaan. Transaksi inilah yang menjadi atensi pemerintah dalam mengeluarkan peraturan-peraturan perpajakan agar dapat memungut pajak atas transaksi untuk membiayai pembangunan di indonesia (Lubis 2015:2) dengan adanya titik ketersingungan akuntansi pajak ini, yaitu transaksi, perusahaan cenderung menerapkan akuntansi yang suda sesuai dengan peraturan pajak atau disebut dengan istilah akuntansi pajak (Tax Accounting).

\subsection{Pajak Daerah}

Pajak daerah merupakan salah satu Pendapatan Asli Daerah di samping Retribusi Daerah, hasil perusahaan Milik Daerah dan hasil Pengelolaan Kekayaan Daerah lainnya yang dipisahkan.

Menurut suandy (2015) pajak daerah adalah pajak yang wewenang pemungutannya ada pada pemerintah daerah yang pelaksanaannya dilakukan oleh Dinas Pendapatan Daerah.

\subsection{Pajak Hotel}

Menurut Sumarto dalam Khotima (2014:5) pajak hotel adalah pajak atas pelayanan hotel. Dasar pengenaan pajak adalah jumlah pembayaraan yang dilakukan oleh subjek pajak kepada hotel (wajib pajak). Tarifnya adalah $10 \%$ (sepuluh persen) dari total pendapatan per bulan.

\subsection{Pendapatan Asli Daerah}

Pendapatan Asli Daerah dapat dikatakan sebagai pendapatan rutin dari usaha-usaha pemerintah daerah dan memanfaatkan potensi-potensi sumber keuangan daerahnya untuk membiayai tugas dan tanggung jawab.

Dengan penjelasan Undang-Undang No. 25 Tahun 1999 diperbarui dengan UndangUndang No. 33 Tahun 2004 tentang perimbangan keuangan antara pusat dan daerah menjelaskan bahwa :

Pembangunan daerah sebagai sebagian integral dari pembangunan nasional dilaksanakan berdasarkan prinsip ekonomi daerah dan pengaturan sumber daya nasional yang memberikan kesempatan bagi peningkatan demokrasi dan kinerja daerah untuk meningkatkan kesejahteraan daerah menuju masyarakat madani yang bebas korupsi, kolusi, dan nepotisme.

Untuk mendorong penyelengaraan otonomi daerah diperlukan kewenangan yang luas, nyata dan bertanggung jawab didaerah secara proposional yang diwujudkan dengan pengaturan, pembagian dan pemanfaatan sumber daya nasional yang berkeadilan, serta pertimbangan keuangan pemerintah pusat dan daerah. 
Sumber-sumber pembiayaan pelaksanaan desentralisasi terdiri dari Pendapatan Asli Daerah (PAD), sumber Pendapatan Asli Daerah merupakan sumber keuangan daerah yang digali dalam wilaya daerah yang bersangkutan, yang terdiri :

1.Pajak Daerah

Pajak Daerah merupakan pajak pungutan daerah menurut peraturan daerah yang dipergunakan untuk membiayai urusan rumah tangga daerah sebagai badan hukum publik.

2.Retribusi Daerah

Retribusi Daerah merupakan pungutan daerah sebagai pembayaran pemakaian atau karena memperoleh jasa atau pekerjaan pelayanan pemerintah daerah dan jasa usaha milik daerah bagi yang berkepentingan atas jasa yang diberikan oleh daerah baik langsung maupun tidak langsung.

3.Bagian Laba Badan Usaha Milik Daerah

Bagian badan usaha milik daerah ialah bagian keuntungan atau laba bersi dari perusahaan daerah atas badan lain yang merupakan badan usaha milik daerah. Sedangkan perusahaan daerah adalah perusahaan yang modalnya sebagian atau seluruhnya merupakan kekayaan milik daerah yang dipisahkan.

4.Lain-Lain Pendapatan Daerah yang Sah

Merupakan penerimaan selain yang disebutkan diatas tapi sah. Penerimaan ini mencangkup sewa, gedung dan tanah milik daerah dan penerimaan-penerimaan lain yang sah menurut Undang-Undang.

\section{METODE PENELITIAN}

\subsection{Jenis Data Dan Sumber Data}

\subsubsection{Jenis Data}

Menurut sugiyono (2014:8\&9) dan (2017:7) ada dua jenis data yang digunakan, yaitu data Kualitatif dan data Kuantitatif.

1. Data kuantitatif, dapat diartikan sebagai metode pasitivistik. Metode ini juga di sebut metode discovery, karena dengan metode ini ditemukan dan dikembangkan berbagai iptek baru. Metode ini disebut kuantitatif karena data dan penelitian berupa angkaangka dan analisis mengunakan statistik.

2. Data kualitatif, yaitu data yang digunakan untuk meneliti pada kondisi objek alamiah, dimana peneliti adalah sebagai instrument kunci, pengambilan sampel sumber data dilakukan secara purposif, teknik pengumpulan dengan trianggulasi, analisis data bersifat induktif/kualitatif, dan hasil penelitian kualitatif lebih menekankan makna dari pada generalisasi.

Penelitian ini digunakan jenis data kualitatif berapa gambaran umum Dinas Pendapatan Pengelolaan Keuangan dan Aset Daerah Kabupaten Halmahera Utara.

\subsubsection{Sumber Data}

Sumber data yang digunakan dalam penelitian ini berupa data sekunder, yaitu data yang dikumpulkan dari Dinas Pendapatan Pengelolaan Keuangan dan Aset Daerah berupa laporan tentang Pajak Hotel Dan PAD Di Kabupaten Halmahera Utara selama periode 20132017.

\subsection{Teknik Pengumpulan Data}

Ada beberapa teknik dalam pengumpulan data antara lain :

a. Wawancara (Interview), yaitu teknik pengumpulan data dengan melakukan tatap muka secara langsung dengan kepala Dinas Pendapatan Pengelolaan Keuangan dan asset Daerah Kabupaten Halmahera Utara beserta karyawan yang ada, yakni dengan mengunakan Tanya jawab sesuai dengan data-data yang diperlukan dalam memecahkan masalah yang dibahas. 
b. Metode pengematan langsung (Observasi), yaitu teknik pengumpulan data dengan cara pencarian dan pengumpulan data yang dilakukan dengan pengamatan secara langsung dilokasi penelitian, yaitu pada Dinas Pendapatan Pengelolaan Keuangan dan Aset Daerah Kabupaten Halmahera Utara.

c. Dokumen, yaitu proses pengumpulan data dengan mempelajari dan menganalisis dokumen yang berkaitan dengan pajak hotel.

d. Studi kepustakaan, yaitu teknik pengumpulan data dengan cara membaca bukubuku, referensi dan literature yang berhubungan dengan penyusunan laporan akhir.

Dalam penelitian ini, teknik pengumpulan data yang digunakan adalah wawancara, observasi, pengumpulan dokumen, dan studi kepustakaan.

\subsection{Metode Analisis}

Jenis penelitian ini mengunakan penelitian deskriptif kualitatif. Deskriptif kualitatif merupakan penelitian yang bertujuan untuk memahami fenomena tentang apa yang dialami oleh subjek penelitian. Misalnya perilaku, persepsi, motivasi, tindakan dan lain-lain secara holistik dan dengan cara deskripsi dalam bentuk kata-kata dan bahasa, pada suatu konteks khusus yang alamiah dan dengan memanfaatkan berbagai metode alamiah.

\subsection{Teknik Analisis}

Teknik analisis yang digunakan dalam penelitian ini adalah:

1. Mengumpulkan informasi yang berhubungan dengan judul penelitian ini melalui jurnal-jurnal.

2. Memperoleh gambaran umum dari objek penelitian secara keseluruhan serta mengetahui permasalahan yang ada.

3. Mengelola data yang diperoleh

4. Menarik kesimpulan dan memberikan saran yang dianggap perlu sebagai perbaikan dalam permasalahan yang ada.

\section{HASIL ANALISIS DAN PEMBAHASAN}

\subsection{Gambaran Umum dan Sejarah Kabupaten Halmahera Utara}

Kabupaten ini dibentuk berdasarkan Undang-Undang No. 1 Tahun 2003 dengan ibu kota terletak di Tobelo yang dibagi menjadi 9 kecamatan dan 174 Desa. Selanjutnya berdasarkan PERDA No. 1-2/2006, wilayah kabupaten di mekarkan menjadi 22 kecamatan dan 260 desa. Dan terakhir dibentuknya Kabupaten Pulau Morotai (UU No.53/2008 ). Wilaya kabupaten menjadi 17 kecamatan dan 196 desa. Secara umum Kabupaten Halmahera Utara adalah wilaya kepulauan di selatan Samudra Pasifik yang merupakan konstalasi pulau-pulau besar dan kecil sebanyak 115 pulau.

\subsection{Hasil Penelitian}

Berdasarkan penelitian yang dilakukan maka penulis dapat memperoleh data-data dari beberapa sumber di antaranya dari Dinas Pendapatan Pengelolaan Keuangan dan Aset Daerah (DPBKAD) Kabupaten Halmahera Utara. Adapun data-data yang diperoleh adalah Realisasi Pendapatan Asli Daerah Tahun 2013-2017 
Tabel 4.1 Realisasi Penerimaan Pajak Hotell Kabupaten Halmahera Utara Tahun 2013-2017

\begin{tabular}{|c|c|c|c|c|}
\hline No & Tahun Angaran & $\begin{array}{c}\text { Target Pajak Hotel } \\
(\mathrm{Rp})\end{array}$ & $\begin{array}{c}\text { Realisasi Pajak Hotel } \\
(\mathrm{Rp})\end{array}$ & Ket \\
\hline 1 & 2013 & 200.000 .000 & 220.401 .700 & Naik \\
\hline 2 & 2014 & 200.000 .000 & 232.157 .500 & Naik \\
\hline 3 & 2015 & 255.276 .000 & 248.722 .205 & Turun \\
\hline 4 & 2016 & 275.000 .000 & 237.367 .950 & Turun \\
\hline 5 & 2017 & 350.000 .000 & 375.435 .250 & Naik \\
\hline
\end{tabular}

Sumber: Dinas Pendapatan Pengelolaan Keuangan Dan Aset Daerah 2018

\section{Pembahasan}

\subsubsection{Analisis Rasio Efektivitas Pajak Hotel}

Efektivitas penerimaan pajak hotel di Kabupaten Halmahera Utara di analisis dengan mengunakan rasio efektivitas dengan rumus sebagai berikut.

$$
\text { Efektivitas }=\frac{\text { Realisasi Penerimaan Pajak Hotel }}{\text { Target Penerimaan Pajak Hotel }} \times 100 \%
$$

\section{Tahun 2013}

Berdasarkan target penerimaan Pajak Hotel sebesar Rp 200.000.000 dengan realisasi yang diperoleh sebesar Rp 220.401.700, maka efektivitas penerimaan Pajak Hotel Tahun 2013 dapat diketahui dengan perhitungan sebagai berikut.

$$
\text { Efektivitas }=\frac{220.401 .700}{200.000 .000} \times 100 \%=110,20 \%
$$

Jadi tingkat efektivitas penerimaan pajak hotel pada tahun 2013 sebesar 110,00\%.

2. Tahun 2014

Berdasarkan target penerimaan Pajak Hotel sebesar Rp 200.000.000 dengan realisasi yang diperoleh sebesar Rp 232.157.500, maka efektivitas penerimaan Pajak Hotel Tahun 2014 dapat diketahui dengan perhitungan sebagai berikut.

$$
\text { Efektivitas }=\frac{232.157 .500}{220.000 .000} \times 100 \%=116,08 \%
$$

Jadi tingkat efektivitas penerimaan pajak hotel pada tahun 2014 sebesar 116,08\%.

3. Tahun 2015

Berdasarkan target penerimaan Pajak Hotel sebesar Rp 255.276.000 dengan realisasi yang diperoleh sebesar Rp 248.722.205, maka efektivitas penerimaan Pajak Hotel Tahun 2015 dapat diketahui dengan perhitungan sebagai berikut.

$$
\text { Efektivitas }=\frac{248.722 .205}{255.276 .000} \times 100 \%=97,43 \%
$$

Jadi tingkat efektivitas penerimaan pajak hotel pada tahun 2015 sebesar 97,43\%. 
4. Tahun 2016

Berdasarkan target penerimaan Pajak Hotel sebesar Rp 350.000.000 dengan realisasi yang diperoleh sebesar Rp 375.435.250, maka efektivitas penerimaan Pajak Hotel Tahun 2016 dapat diketahui dengan perhitungan sebagai berikut.

$$
\text { Efektivitas }=\frac{375.435 .250}{350.000 .000} \times 100 \%=107,27 \%
$$

Jadi tingkat efektivitas penerimaan pajak hotel pada tahun 2017 sebesar 107,27\%.

5. Tahun 2017

Berdasarkan target penerimaan Pajak Hotel sebesar Rp 255.276.000 dengan realisasi yang diperoleh sebesar Rp 248.722.205, maka efektivitas penerimaan Pajak Hotel Tahun 2013 dapat diketahui dengan perhitungan sebagai berikut.

$$
\text { Efektivitas }=\frac{248.722 .205}{255.276 .000} \times 100 \%=97,43 \%
$$

Jadi tingkat efektivitas penerimaan pajak hotel pada tahun 2015 sebesar 97,43\%.

Berdasarkan rumus efektivitas diatas, dapat diketahui tingkat efektivitas pajak hotel di Kabupaten Halmahera Utara tahun anggaran 2013-2017, untuk lebih jelasnya dapat dilihat pada table berikut.

Tabel 4.2 Efektivitas Penerimaan Pajak Hotel Kabupaten Halmahera Utara Tahun 2013-2017

\begin{tabular}{|c|c|c|c|c|c|}
\hline No & Tahun & $\begin{array}{c}\text { Target Pajak } \\
\text { Hotel (Rp) }\end{array}$ & $\begin{array}{c}\text { Realisasi Pajak } \\
\text { Hotel (Rp) }\end{array}$ & $\begin{array}{c}\text { Tingkat } \\
\text { Efektivitas }(\%)\end{array}$ & Keterangan \\
\hline 1 & 2013 & 200.000 .000 & 220.401 .700 & $110,20 \%$ & Sangat Efektif \\
\hline 2 & 2014 & 200.000 .000 & 232.157 .500 & $116,08 \%$ & Sangat Efektif \\
\hline 3 & 2015 & 255.276 .000 & 248.722 .205 & $97,43 \%$ & Efektif \\
\hline 4 & 2016 & 275.000 .000 & 237.367 .950 & $86,32 \%$ & Kurang Efektif \\
\hline 5 & 2017 & 350.000 .000 & 375.435 .250 & $107,27 \%$ & Sangat Efektif \\
\hline
\end{tabular}

Sumber: Data Diolah, 2018

Dikatakan sangat efektif karena kreteria efektif $>100 \%$ dan realisasi pajak hotel mencapai target pajak hotel sebesar 116,08\%. Dan dikatakan kurang efektif karena kreteria efektif hanya mencapai $60 \%-80 \%$ sehinga realisasi pajak hotel tidak mencapai target pajak hotel sebesar $85,32 \%$.

\subsubsection{Analisis Kontribusi Pajak Hotel}

Kontribusi pajak daerah khususnya Pajak Hotel terhadap Pendapatan Asli Daerah merupakan suatu rasio yag digunakan untuk mengetahui seberapa besar sumbangan pajak hotel terhadap Pendapatan Asli Daerah di Kabupaten Halmahera Utara. Untuk menghitung besar Kontribusi Pajak Hotel mengunakan rumus sebagai berikut.

$$
\text { Kontribusi }=\frac{\text { Realisasi Pajak Hotel }}{\text { Realisasi Pendapatan Asli Daerah }} \times 100 \%
$$


1. Tahun 2013

$$
\text { Kontribusi }=\frac{220.401 .700}{103.330 .459 .759} \times 100 \%=2,13 \%
$$

Dari hasil perhitungan diatas dapat diperoleh penerimaan Kontribusi Pajak Hotel terhadap Pendapatan Asli Daerah Kabupaten Halmahera Utara pada tahun 2013 sebesar 2,13\%

2. Tahun 2014

$$
\text { Kontribusi }=\frac{232.157 .500}{112.606 .899 .652} \times 100 \%=2,06 \%
$$

Dari hasil perhitungan diatas dapat diperoleh penerimaan Kontribusi Pajak Hotel terhadap Pendapatan Asli Daerah Kabupaten Halmahera Utara pada tahun 2014 sebesar 2,06\%.

3. Tahun 2015

$$
\text { Kontribusi }=\frac{248.722 .205}{136.456 .249 .662} \times 100 \%=1,82 \%
$$

Dari hasil perhitungan diatas dapat diperoleh penerimaan Kontribusi Pajak Hotel terhadap Pendapatan Asli Daerah Kabupaten Halmahera Utara pada tahun 2015 sebesar 1,82\%.

4. Tahun 2016

$$
\text { Kontribusi }=\frac{237.367 .950}{79.494 .461 .887} \times 100 \%=2,98 \%
$$

Dari hasil perhitungan diatas dapat diperoleh penerimaan Kontribusi Pajak Hotel terhadap Pendapatan Asli Daerah Kabupaten Halmahera Utara pada tahun 2016 sebesar 2,98\%.

5. Tahun 2017

$$
\text { Kontribusi }=\frac{375.435 .250}{152.028 .897 .731} \times 100 \%=2,47 \%
$$

Tabel 4.3 Kontribusi Pajak Hotel Terhadap Pendapatan Asli Daerah di Kabupaten Halmahera Utara Tahun 2013-2017

\begin{tabular}{|c|c|c|c|c|c|}
\hline No & Tahun & $\begin{array}{c}\text { Realisasi Pajak } \\
\text { Hotel (Rp) }\end{array}$ & $\begin{array}{c}\text { Kontribusi } \\
\text { Pendapatan Asli } \\
\text { Daerah (Rp) }\end{array}$ & Kontribusi (\%) & Keterangan \\
\hline 1 & 2013 & 220.401 .700 & 103.330 .459 .759 & $2,13 \%$ & Sangat Kurang \\
\hline 2 & 2014 & 232.157 .500 & 112.606 .899 .652 & $2,06 \%$ & Sangat Kurang \\
\hline 3 & 2015 & 248.722 .205 & 136.456 .249 .662 & $1,82 \%$ & Sangat Kurang \\
\hline 4 & 2016 & 237.367 .950 & 79.494 .461 .887 & $2,99 \%$ & Sangat Kurang \\
\hline 5 & 2017 & 375.435 .250 & 152.028 .897 .731 & $2,47 \%$ & Sangat Kurang \\
\hline
\end{tabular}

Sumber: Data Diolah, 2018

Kontribusi pendapatan asli daerah dikatakan sangat kurang karena presentase kontribusi hanya mencapai $0,00 \%-10 \%$ dan dinyatakan sangat baik jika presentase kontribusinya meningkat sebesar 50\% dan kontribusi pendapatan asli daerah di Kabupaten Halmahera Utara selama tahun 2013-2017 dikatakan sangat kurang karena kontribusi pendapatan asli daerah masi kurang sehingga kontribusinya hanya mencapai 0,00\%-10\% (sangat kurang). 


\section{KESIMPULAN DAN SARAN}

\subsection{Kesimpulan}

Penelitian ini dimaksudkan untuk menganalisis efektivitas dan kontribusi pajak hotel terhadap PAD di Kabupaten Halmahera Utara tahun 2013-2017.

1. Tingkat Efektif dari Penerimaan Pajak Hotel tahun 2013-2017 selalu berhasil mencapai target bahkan lebih dari target yang ditentukan, dengan kategori "Sangat Efektif”, karena presentase tingkat efektivitas selalu melebihi diangka 100\%. Tahun 2014 merupakan tingkat efektivitas pajak hotel tertinggi sebesar 116,08\% karena realisasi pajak hotel mecapai target pajak hotel. Sedangkan yang terendah berada pada tahun 2016 sebesar 86,32\% karena realisasi pajak hotel tidak mencapai target pajak hotel.

2. Kontribusi Pajak Hotel terhadap Pendapatan Asli daerah (PAD) Kabupaten Halmahera Utara tahun 2013-2017 dari tahun ke tahun selalu mengalami penurunan dengan kriteria kontribusi "Sangat Kurang" sangat mempengaruhi jumlah PAD yang diterima oleh Pemerintah Kabupaten Halmahera Utara. Tahun 2016 merupakan kontribusi tertinggi Pajak Hotel terhadap PAD sebesar 2,99\% dan pada tahun 2015 merupakan kontribusi terendah sebesar $1,82 \%$. Karena kontribusi pendapatan asli daerah terlalu rendah dibandingkan dengan realisasi pajak hotel.

\subsection{Saran}

Berdasarkan hasil penelitian dan pembahasan yang dilakukan penulis maka, sebagai bahan pertimbangan agar tingkat efektivitas dan kontribusi penerimaan pajak hotel dapat lebih optimal maka dari itu diperlukan lagi beberapa penyempurnaan atas kekurangan yang ada sebelumnya. Untuk itu penulis mengemukakan saran sebagai berikut.

1. Dinas Pendapatan Pengelolaan Keuangan dan Aset Daerah Kabupaten Halmahera Utara diharapkan terus meningkatkan kinerjanya agar profesionalitas pekerjaan terus membaik dan tingkat efektivitas yang suda baik tetap terus konsisten terlebih bisa meningkat.

2. Kontribusi Pajak Hotel masi sangat kurang sehingga pemerintah harus lebih memperhatikan dan mencari solusi atau cara dalam meningkatkan kontribusi dari pajak hotel dengan cara mengali potensi-potensi yang ada, mencari jaringan dari luar kota bahkan dari luar daerah untuk peningkatan pembangunan hotel yang ada di Kabupaten Halmahera Utara.

\section{DAFTAR PUSTAKA}

Adam, Aldo (2013), hubungan jumlah wisatawan, jumlah hotel, terhadap penerimaan pajak hotel. Jurnal EMBA : Fakultas Ekonomi dan Bisnis, Universitas Sam Ratulangi Manado.

Khotimah, Qusnul (2014) Analisis Potensi Dan Efektivitas Penerimaan Pajak Hotel Dalam Meningkatakan Pendapatan Asli Daerah. Fakultas Ekonomi dan Bisnis, Universitas Brawijaya, Malang.

Heince R.N Wokas, Hasanudin. (2013), Analisis efektifitas dan kontribusi pajak kendaraan bermotor terhadap penerimaan PAD di Provinsi Maluku

Utara. Skripsi Fakultas Ekonomi Dan Bisnis Program Pendidikan

Akuntansi Universitas Sam Ratulangi Manado

Lubis Irsan, (2015), Mahir Akuntansi Pajak Terapan Berbasis Standar Akuntansi \& Ketentuan Pajak Terbaru. Penerbit Andi. Yokyakarta.

Lamia, Alfan, (2015), Analisis Efektifitas dan Kontribusi Pemungutan Pajak Restoran, Pajak Reklame, dan Pajak Penerangan Jalan Pada Pendapatan Asli Daerah Kabupaten 
Minahasa Utara. Jurnal EMBA: Fakultas Ekonomi dan Bisnis, Universitas Sam Ratulangi, Manado.

Sugiyono. (2017:7) dan (2014:8\&9) Memahami penelitian kualitatif. Bandung; Alfabeta.

Sondakh Juli, Ibrahim Driyana \& Wangkar Aneke. 2016. Analisis Perbandingan Potensi Penerimaan dan Efektivitas Pajak Penerangan Jalan Kabupaten Minahasa Tengara. Fakultas Ekonomi dan Bisnis, Universitas Sam Ratulangi Manado

Undang-Undang Republik Indonesia Nomor 33 Tahun 2004 Tentang Perimbangan Keuangan Pemerintah Pusat dan Daerah.

Walakandouw, Randy (2013) Analisis Kontribusi Pajak Hotel Terhadap Pendapatan Asli Daerah (PAD) Di Kota Manado. Jurnal EMBA, Fakultas Ekonomi dan Bisnis, Universitas Sam Ratulangi, Manado.

Yuliartini, Putu Intan (2015), Efektivitas Pemungutan Pajak Hotel dan Restoran Pada Pemerintah Daerah Kota Denpasar, Fakultas Ekonomi dan Bisnis, Universitas Udayana (Umud), Bali.

Puspitasari, Diana Amelia (2015), Analisis Efektivitas dan Kontribusi Pajak Hotel dan Restoran Terhadap Penerimaan Asli daerah Kota Bontang Tahun 2012-2014. Fakultas ekoomi, Universitas Negeri Surabaya. 